УДК 612.017.2

\author{
М. В. Горіла
}

Дніпропетровський національний університет ім. Олеся Гончара

\title{
МЕТОДИЧНІ ПІДХОДИ \\ ДО ОЦІНКИ ВПЛИВУ КСЕНОБІОТИКІВ \\ НА БІЛКОВІ МОЛЕКУЛИ
}

\begin{abstract}
Запропоновано комплексний методичний підхід у дослідженнях впливу ксенобіотичних речовин на молекули білків. Із цією метою застосовували три групи методів дослідження: турбідиметричні, імунохімічні та вивчення впливу на ізоелектричну точку білків. Імунохімічні методи найспецифічніші. Турбідиметричні методи найбільш швидкі у часі та інформативні. Слід підкреслити комплексність і універсальність запропонованих методичних підходів. Зазначені методи досліджень ефективні для вивчення впливу ксенобіотиків на білки живих організмів за умови їх комплексного застосування. Даний методичний підхід адекватний, інформативний і досить простий у виконанні.
\end{abstract}

\section{М. В. Горелая}

Днепропетровский наџиональный университет им. Олеся Гончара

\section{МЕТОДИЧЕСКИЕ ПОДХОДЫ \\ К ОЦЕНКЕ ВЛИЯНИЯ КСЕНОБИОТИКОВ НА МОЛЕКУЛЫ БЕЛКОВ}

\begin{abstract}
Предложен комплексный методический подход в исследовании влияния ксенобиотических веществ на молекулы белков. С этой целью применялись три группы методов исследования: турбидиметрические, иммунохимические, а также изучение влияния на изоэлектрическую точку белков. Иммунохимические методы наиболее специфичны. Турбидиметрические методы являются наиболее быстрыми во времени и информативными. Необходимо подчеркнуть комплексность и универсальность предложенных методических подходов. Указанные методы исследований являются эффективными для изучення влияния ксеобиотиков на белки живых организмов при условии их комплексного использовання. Данный методический подход является адекватным, информативным и простым в осуществлении.
\end{abstract}

\author{
M. V. Gorelaya
}

Oles' Honchar Dnepropetrovsk National Uuniversity

\section{METHODOLOGICAL APPROACH TO THE EVALUATION OF XENOBIOTIC ENFFLUECE ON PROTEIN MOLECULES}

It was tested and integrated the methodological approach to the research of xenobiotic compounds impact on protein molecules. For this purpose three groups of research methods were used: turbidimetry, immunochemistry and study of the impact on isoelectric point of proteins. The immunochemical methods are most specific. The turbidimetric methods are fastest and informative. Actually, the proposed methodological approach is integrated and versatile. These methods are effective for studying the xenobiotic influence on proteins in living organisms on the assumption of its complex applications. It was proved that this methodological approach is adequate, informative and easy to use.

(C) М. В. Горіла, 2012 


\section{Вступ}

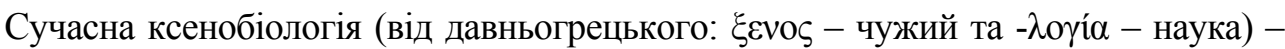
наука, що вивчає чужорідні хімічні сполуки в живому організмі та біологічні реакції, які викликаються цими речовинами. Це галузь біології та міждисциплінарна наука. Предмет ксенобіології - уявлення про механізми надходження, біотрансформації, розподілу, біоконцентрації ксенобіотиків і характер біологічних реакцій, що викликаються чужорідними організму сполуками на різних рівнях організації живих систем [5;8;11]. Ксенобіотики - чужорідні для організму хімічні речовини. Вони не є природними метаболітами живих організмів, не входять до природного біотичного кругообігу, оскільки породжені активною господарською діяльністю людини [6; 8; 10; 11$]$.

За останніми даними, описано в основному два типи біотрансформації ксенобіотиків [6; 11]. Перша фаза метаболізму загалом може бути визначена як етап біотрансформації, протягом якого до молекули сполуки або приєднуються полярні функціональні групи, або здійснюється експресія таких груп, що містяться у субстраті у прихованій формі. Це досягається або шляхом окиснення, або (значно рідше) відновлення молекул за допомогою оксидоредуктаз, або шляхом їх гідролізу естеразами та амідазами. Друга фаза - етап біологічної кон'югації проміжних продуктів метаболізму з ендогенними молекулами, такими як глутатіон, глюкуронова кислота, сульфат тощо. Специфічні системи транспорту кон'югованих дериватів забезпечують ïх виведення 3 організму. Важливий у цьому плані підбір методів виявлення та дослідження чужорідних сполук у живих організмах.

Актуальність проблем сучасних токсикології та біології ксенобіотиків зумовлена підвищенням захворюваності та поширеності патології різних органів, їх прогресуючим перебігом, що призводить до погіршення якості життя, інвалідизації та навіть смерті хворих.

Мета роботи - з'ясувати, якими можуть бути оптимальні, не затратні та максимально інформативні методи оцінки впливу малих доз ксенобіотичної речовини на білки живих організмів.

\section{Матеріал і методи досліджень}

Для даного дослідження брали білки крові ссавців: сироватковий альбумін людини, сироватковий альбумін бика, альфа-2-макроглобулін, імуноглобуліни, гемоглобін людини. Як ксенобіотичні речовини використовували комплексні сполуки ренію, синтезовані в ДВНЗ «Український державний хіміко-технологічний університет» (м. Дніпропетровськ) [1; 12; 14-17]. Ці сполуки мали різний склад, цис- та трансізомери (табл. 1).

Табличя 1

Деякі комплексні сполуки ренію, що досліджувалися

\begin{tabular}{|c|c|c|}
\hline $\begin{array}{l}\text { Скоро- } \\
\text { чення }\end{array}$ & Номенклатурна назва & Формула \\
\hline Re-1 & Транс-дихлоротетрахлороди- $\mu$-аланілдиренат (III) & Tранс-Re $2\left[\mathrm{Ala}_{2} \mathrm{Cl}_{4}\right] \mathrm{Cl}_{2}$, \\
\hline Re-2 & Цис-дихлоротетрахлороди- $\mu$-аланілдиренат (III) & Цис- $\mathrm{Re}_{2}\left[\mathrm{Ala}_{2} \mathrm{Cl}_{4}\right] \mathrm{Cl}_{2}$, \\
\hline Re-3 & Діакватетрахлороди- $\mu$-ацетатодиреній (III) & $\mathrm{Re}_{2} \mathrm{Ac}_{2} \mathrm{Cl}_{4} \cdot 2 \mathrm{H}_{2} \mathrm{O}$ \\
\hline Re-4 & Діакватетрабромоди- $\mu$-ацетатодиреній (III) & $\mathrm{Re}_{2} \mathrm{Ac}_{2} \mathrm{Br}_{4} \cdot 2 \mathrm{H}_{2} \mathrm{O}$ \\
\hline Re-5 & Цезій діакватетра- $\mu$-гідрофосфатодиренат (III) & $\mathrm{Cs}_{2}\left[\mathrm{Re}_{2}\left(\mathrm{HPO}_{4}\right)_{4}\right] \cdot 2 \mathrm{H}_{2} \mathrm{O}$ \\
\hline Re-6 & Тетрахлороди- $\mu$-ізобутиратодиреній (III) дигідрат & $\mathrm{Re}_{2}\left(\mathrm{i} 3 \mathrm{O}-\mathrm{C}_{3} \mathrm{H}_{7} \mathrm{COO}\right)_{2} \mathrm{Cl}_{4} \cdot 2 \mathrm{H}_{2} \mathrm{O}$ \\
\hline Re-7 & 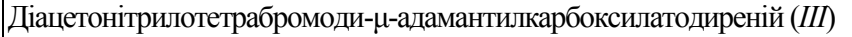 & $\mathrm{Re}_{2}(\mathrm{AdCOO})_{2} \cdot \mathrm{Br}_{4} \cdot 2 \mathrm{CH}_{3} \mathrm{CN}$ \\
\hline Re-8 & ДМФА-тетрахлороди- $\mu$-ацетатодиреній (III) & $\mathrm{Re}_{2} \mathrm{Ac}_{2} \mathrm{Cl}_{4} \cdot \mathrm{DMPA}$ \\
\hline Re-9 & Суміш Re-1 з цис-платином у співвідношенні (4:2) наноліпосомна форма & $\operatorname{Re}-1+\mathrm{cPt}(4: 2) \mathrm{nlp}$ \\
\hline
\end{tabular}


Метод турбідиметрії проводили за таким протоколом. Білки крові людини (альбумін, гемоглобін і макроглобулін) отримували від Sigma Aldrich, США, без додаткового очищення. Готували водні розчини білків у концентрації $10^{-4}$ моль/л. Додавали до розчинів білків сполуки ренію, отримуючи співвідношення «білок / сполука ренію» $100 / 1,10 / 1,1 / 1,1 / 10$. Проводили заміри оптичної густини на спектрофотометрі КФК-2-УХЛ4.2 за довжини хвилі $\lambda=720$ нм у часовій динаміці з інтервалом $5,15,35,65$, 125 хвилин. Будували графік залежності інтенсивності поглинання (А) від часу (Т, хв). Швидкість коагуляції розраховували шляхом апроксимації лінії росту поглинання розчину від початку утворення коагулянта $\left(\mathrm{A}_{0}\right)$ до максимуму поглинання $\left(\mathrm{A}_{\text {макс }}\right)$ протягом певного часу за формулою: $\mathrm{A}_{\text {макс }}-\mathrm{A}_{0} / \mathrm{T}_{\text {макс }}-\mathrm{T}_{0}, \mathrm{xB}^{-1}$.

Імунодифузію за Ухтерлоні, імунодифузію за Манчині та імуноелектрофоретичні методи використовували для оцінки впливу ксенобіотиків на процеси взаємодії антигенів з антитілами. Готували водні розчини сполук у діапазоні концентрацій від $10^{-3}$ до $10^{-11}$. Взаємодію «антиген - антитіло» вивчали за допомогою методів імунодифузії за Ухтерлоні та Манчині, а також методів ракетного та перехресного імуноелектрофорезів [2-4]. Як антиген використовували стандартну сироватку крові людини (виробництво підприємства бакпрепаратів ДНДІЕМ, м. Нижній Новгород, Росія) і груп здорових донорів, сироватковий альбумін людини. Антитілами були: моноспецифічні сироватки проти $\operatorname{IgA}, \operatorname{IgG}, \operatorname{IgM}$, поліспецифічні сироватки проти білків крові людини (виробництво підприємства бакпрепаратів ДНДІЕМ, м. Нижній Новгород, Росія). Досліди проводили за умови попередньої інкубації сполук ренію з антигеном $\left(+37^{\circ} \mathrm{C}\right.$, 1 год). Усі експерименти проводили у шестиразовій повторності.

Вивчали зсуви імунопреципітаційних ліній під час імунодифузії за Ухтерлоні, зміни діаметра преципітаційних кіл із пластинок імунодифузії за Манчині та зміни площі імуноелектрофоретичних піків із пластинок ракетного та перехресного імуноелектрофорезів порівняно з контролем. Загальний білок визначали методом Лоурі.

Для визначення впливу ксенобіотиків на ізоелектричну точку білків як модельні білки використовували сироваткові альбуміни людини та бика. Готували водні розчини білків із концентрацією $1 \%$. За допомогою натрій-ацетатного буфера створювали буферне середовище з різними значеннями $\mathrm{pH}$ у діапазоні 4,1-5,9. Досліджувані білки попередньо інкубували з розчинами комплексних сполук у різних концентраціях протягом 1 год при $+37^{\circ} \mathrm{C}$, як і в інших методиках. Суміші білків із ксенобіотиками після інкубації переносили до буферних середовищ і ретельно перемішували. При змішуванні розчинів у кожній пробірці встановлювалася певна концентрація іонів водню $(p H)$. Вміст пробірок добре перемішували. Через 5-10 хвилин у всіх пробірках з'являвся осад (помутніння). Найбільша кількість осаду спостерігалася в тій пробірці, $p H$ якої відповідала ізоелектричній точці даного білка. Для посилення ефекту у пробірки повільно по стінці доливали розчин етилового спирту, спостерігали за формуванням осаду протягом 30 хв і вимірювали ступінь помутніння на спектрофотометрі КФК-2-УХЛ4.2. Будували графік залежності оптичної густини від концентрації комплексних сполук і значення $\mathrm{pH}$. Статистичну обробку проводили із застосуванням однофакторного дисперсійного аналізу [7].

\section{Результати та їх обговорення}

Турбідиметричні методи оцінки впливу комплексних сполук на білкові молекули виявилися найпростішими, найдешевшими та найінформативнішими 3 усього запропонованого спектра методів. За допомогою таких методів можна встановити сам факт взаємодії речовини з білком, кількісно оцінити реагування у часовій динаміці. 
При переході на кількісний варіант методу з'являється можливість вирахувати швидкість утворення коагуляту. Найбільш демонстративні отримані дані $з$ цього методу порівняно з контролем наведені на рисунку 1.

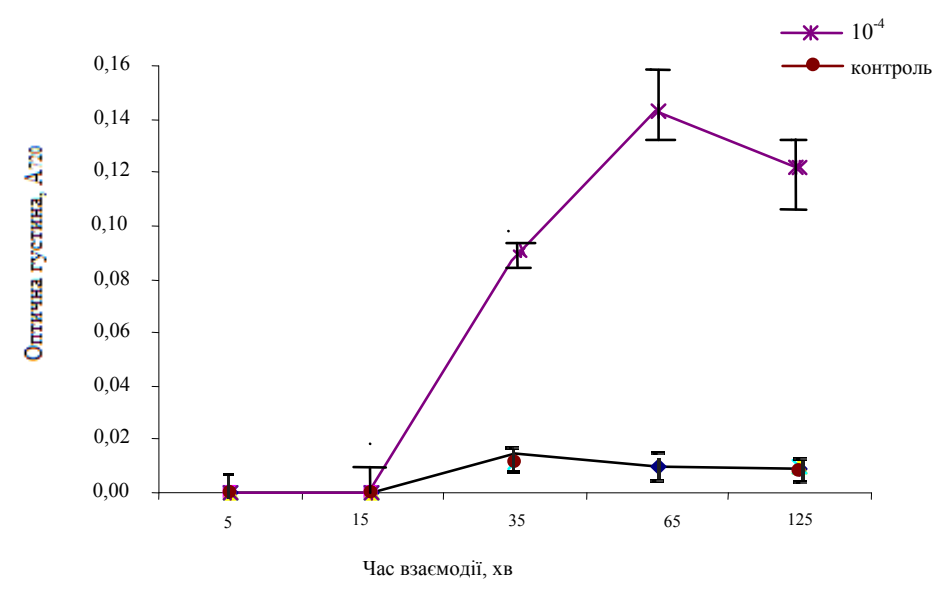

Рис. 1. Залежність оптичної густини розчину гемоглобіну $\mathbf{A}_{720}\left(10^{-4}\right.$ моль/л)

із комплексом ренію Re-2 (цис-дихлоротетрахлороди-ц-аланілдиренат (III)) $\left(10^{-4}\right.$ моль/л) від часу взасмодії $(\mathbf{x в}, n=6)$

За результатами турбідиметрії всіх досліджуваних ксенобіотиків - комплексів ренію виявилося можливим їх класифікувати та поділити на групи: швидко, повільно реагуючі та нереагуючі комплексні сполуки.

Блок імунохімічних методів дослідження містив як методи імунодифузії, так і методи імуноелектрофорезу, за допомогою яких з'ясовувався вплив ксенобіотиків на взаємодію «антиген - антитіло». Встановлено, що ці агенти являють собою низькотоксичні речовини, які радикально не змінюють хід взаємодії «антиген - антитіло» та не розчиняють утворені імунопреципітати. Лінії преципітації в усіх випадках чітко виявлені. Загалом із гістограм (для зразка одна з них подана на рисунку 2) можна зробити такі висновки, що в діапазоні концентрацій ксенобіотика $10^{-6}-10^{-10}$ моль/л спостерігалася зміна характеру впливу на взаємодію. Майже в усіх випадках, крім взаємодії 3 IgG, спостерігалося слабке пригнічення взаємодії «антиген - антитіло» (на 10 \% у середньому) порівняно з контролем.

Попередню інкубацію комплексних сполук ренію проводили як окремо $з$ антигенами та 3 антитілами, так і одночасно 3 антигенами та 3 антитілами. Отримано аналогічні результати, які підтвердили в цілому м'яку недеструктивну супресивну дію цих ксенобіотичних сполук. За допомогою методу однофакторного дисперсійного аналізу обрахували силу впливу цих комплексів на білки. Сила впливу реній-цисплатинового наноліпосомного комплексу (Re-1+cPt (4:2) nlp) (водна суспензія) в результаті імунодифузії становить $35,8 \%$, а в результаті імуноелектрофорезу - 38,3 \%; сила впливу реній-цисплатинового наноліпосомного комплексу $(\operatorname{Re}-1+\mathrm{cPt}(4: 2) \mathrm{nlp})$ (розчин у $3 \mathrm{M} \mathrm{KCl}$ ) у результаті імунодифузії становить $44,0 \%$, а в результаті імуноелектрофорезу $-42,0 \%$.

Отже, даним дослідженням відкрито новий перспективний аспект застосування відомих імунохімічних методів у галузі біохімічної трансформації ксенобіотиків на рівні молекул. 


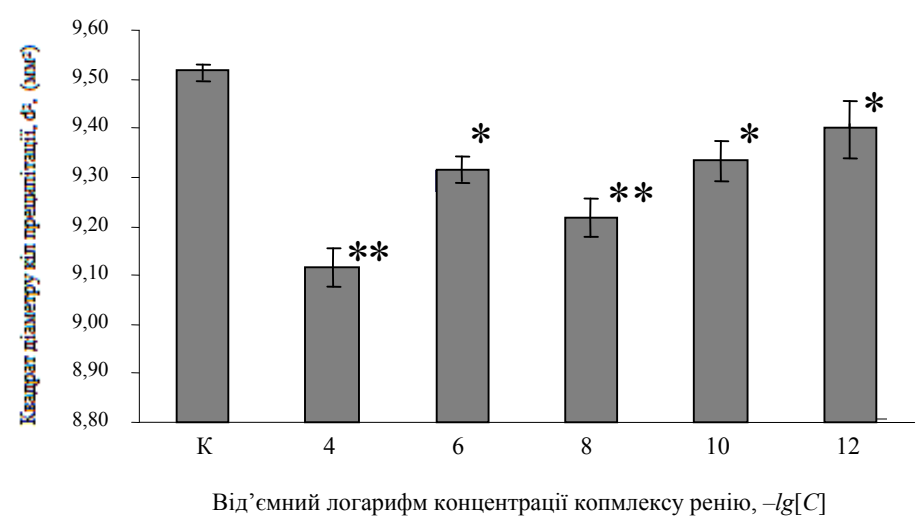

Рис. 2. Вплив $\operatorname{Re}_{2} \boldsymbol{A c}_{2} \mathrm{Cl}_{4} \bullet \mathrm{DMPA}$ на реакцію «антиген - антитіло» в умовах преінкубації $3 \operatorname{IgA}$ $(\boldsymbol{n}=\mathbf{6})$ : вісь абсцис $-K$-контроль, 4, 6, 8, 10, 12 - від'ємний логарифм концентрації комплексів ренію (Моль/л), вісь ординат - квадрат діаметра кіл преципітації $\left(\mathrm{мм}^{2}\right){ }^{*}$ - достовірна відмінність відносно контролю $(p<0,05), * *$ - достовірна відмінність відносно контролю $(p<0,01)$

Методи визначення ізоелектричної точки білків модифіковано 3 метою з'ясування наявності змін у значеннях ізоелектричної точки білків сироватки крові після інкубації їх із комплексними сполуками у різних концентраціях. Суттєвих зсувів не виявлено, що підтверджує помірну недеструктивну дію сполук ренію (зміни у сотих долях $p H$ зафіксувати вдалося).

\section{Висновки}

Три групи використаних методів мають свої переваги та недоліки. Імунохімічні методи найспецифічніші. Решта методів у цьому плані дещо програє. Турбідиметричні методи найшвидші у часі та найінформативніші. Також слід підкреслити комплексність і універсальність запропонованих методичних підходів. Об'єкти досліджень можуть бути найрізноманітніші (як молекули білків, так і ксенобіотики) за умов вирішення проблеми розчинності всіх агентів реагування. На початковому етапі досліджень такий методичний арсенал цілком виправдав себе, зокрема 3 погляду незатратності, адекватності, специфічності, комплексності підходу та інформативності.

У подальшому слід переходити до складніших, специфічніших і чутливіших методів досліджень (наприклад, інфрачервона спектроскопія білкових молекул, методи оцінки спектрів кругового дихроїзму тощо). Далі розкриваються можливості для залучення методів комп'ютерного моделювання взаємодії білків із чужорідними агентами. Зазначені методи досліджень ефективні для вивчення впливу ксеобіотиків на білки живих організмів за умови їх комплексного застосування.

\section{Бібліографічні посилання}

1. Взаємодія сироваткових альбумінів з кластерними сполуками ренію цис- і транс-конфігурації / I. В. Леус, I. О. Кленіна, К. А. Заболоцька та ін. // Biopolymers\&Cells. - 2011. - Т. 27, № 6. C. $460-466$.

2. Вплив кластерних сполук ренію та протипухлинної системи реній-платина на білки плазми крові / М. В. Горіла, Т. М. Полішко, І. А. Кленіна, Н. І. Штеменко // Медична хімія. - 2011. T. 11, № 3. - С. 60-64. 
3. Горелая М. В. Влияние кластерных соединений рения на взаимодействие сывороточного альбумина человека с антителами / М. В. Горелая, Л. М. Александрова, Н. И. Штеменко // Зб. наук. пр. Луганськ. нац. аграрн. ун-ту. - 2004. - Т. 51, № 39. - С. 83-86.

4. Закономірності взаємодії антиген - антитіло у розчинах кластерних сполук ренію та цисплатину / М. В. Горіла, Т. М. Полішко, А. М. Аношко та ін. // Вісник Дніпропетр. ун-ту. Біологія. Екологія. - 2009. - Вип. 17, т. 2. - С. 37-40.

5. Камышников В. С. Справочник по клинико-биохимической лабораторной диагностике. В 2 т. - Минск : Беларусь, 2000. - 465 с.

6. Куценко С. А. Основы токсикологии. - М. : Медицина, 2002. - 286 с.

7. Лакин Г. Ф. Биометрия. - М. : Высш. шк., 1990. - 352 с.

8. Назаренко Г. И. Клиническая оценка результатов лабораторных исследований / Г. И. Назаренко, А. А. Кишкун. - М. : Медицина, 2002. - 541 с.

9. Пшенкина Н. Н. Взаимодействие лекарственных веществ с сывороточным альбумином. СПб. : НИИ экспериментальной медицины СЗО РАМН, 2001. - 234 с.

10. Тиунов Л. А. Основы механизма метаболизма ксенобиотиков в организме человека и животных // Итоги науки и техники. Сер. Токсикология. - М. : Мир, 1981. - Т. 12. - С. 19-40.

11. Hayes A. W. (Ed.) Principles and Methods of Toxicology. - 2nd ed. - New York : Raven Press, 1989. $-929 \mathrm{p}$.

12. Liposomal forms of rhenium cluster compounds: Enhancement of biological activity / N. I. Shtemenko, E. D. Zhabitskaya, O. V. Bersenina et al. // Chemistry \& Biodiversity. - 2008. - Vol. 5. P. $1660-1667$.

13. Physical stability of proteins in aqueous solution: Mechanism and driving forces in nonnative protein aggregation / E. Y. Chi, S. Krishnan, T. W. Randolph, J. F. Carpenter // Pharm. Res. - 2003. Vol. 20. - P. 1325-1336.

14. Shtemenko A. V. Chemistry of binuclear Rhenium clusters / A. V. Shtemenko, B. A. Bovikyn // Rhenium and Rhenium Alloys. - Pensilvania : TMS publications, 1997. - P. 189-197.

15. Shtemenko N. I. Interaction of Rhenium cluster compounds with human blood proteins / N. I. Shtemenko, M. V. Gorelaya, L. M. Alexandrova // Metal Ions in Biology and Medicine. 2002. - Vol. 7. - P. 34-36.

16. Shtemenko N. Dichlorotetra- $\mu$-isobutiratodirhenium (III): Enhancement of cisplatin action and KBC stabilizing properties / N. Shtemenko, P. Collery, A. Shtemenko // Anticancer Research. - 2007. Vol. 27. - P. 2487-2492.

17. Shtemenko N. I. Recent advantages in application of cluster rhenium compounds as antitumor agents / N. I. Shtemenko, P. Collery, A. V. Shtemenko // Metal Ions in Biology and Medicine / Ed. P. Collery, I. Maymard, T. Theophanides et al. - John Libbey Eurotext. - 2008. - Vol. 10. - P. 441-445.

Надійшла до редколегї 01.03.2012 